\title{
A Comparative Study of Waste Cooking Oil Recycling Programs in Bogor and Niigata Cities and GHG Emission Reduction by Recycling
}

\author{
Haruhiro Fujita ${ }^{1}$, Wataru Iijima ${ }^{2}$, Katsuyuki Nakano ${ }^{3}$, Joko Prayitno ${ }^{4}$, Hiroe Tsubaki ${ }^{5}$, Genshiro Kitagawa ${ }^{6}$ \\ ${ }^{1}$ Department of Information Systems, Niigata University for International and Information Studies, Japan \\ ${ }^{2}$ National Agricultural Research Center, Biomass Production \& Processing Res. Team, Tsukuba, Japan \\ ${ }^{3}$ Japan Environment Management Association for Industry, Tokyo, Japan \\ ${ }^{4}$ Center for Environment Technology, Agency for Assessment and Application of Technology, Indonesia \\ ${ }^{5}$ Research Organization of Information and Systems, Institute of Statistical Mathematics, Tokyo, Japan \\ ${ }^{6}$ Research Organization of Information and Systems, Tokyo, Japan
}

\begin{abstract}
In indonesia, a substantial waste cooking oil from households is being disposed to drainage and soil, according to the recent survey conducted in bogor, causing environmental damages of water and soil pollutions, as well as increase in ghg emission. in urban areas of Japan, waste cooking oil is mostly being solidified and disposed as incinerating waste, whereas in local areas, it is being disposed into drainage and causing sewage system deterioration.

The waste cooking oil recycling programs conducted by Bogor and Niigata cities were reviewed highlighting environmental and economical issues. Similarities were found, in total waste cooking oil amounts collected, and the $60 \%$ ratio of total recycled bio diesel fuel for their vehicle operations.

Life cycle impacts in GHG emission of cooking oil were estimated using operationaldata of a factory as well as reported data of LCA studies. The environmental advantage of the waste cooking oil recycling, compared with the drainage and soil disposals as well as the complete use, did not necessarily encourage the recycling activities, due to economical and technical constraints, the latter case in the Bogor City seems to be easily overcome, than the issues of high labour costs in Japan.
\end{abstract}

Keywords-GHG emission; waste cooking oil; recycled energy; bio diesel fuel; life cycle impacts; LCA.

\section{REVIEW OF CURRENT WASTE COOKING OIL DISPOSALS AND RECYCLING}

Comparison of current waste cooking oil disposals and recycling between Indonesia and Japan in social, environmental issues and legislation were made as in Table 1.

In Indonesia, most of households' waste cooking oil (hereafter WCO) is being disposed to either drainage or soil (being reported in Chapter 3), causing substantial drainage and edaphic pollution, where the sewage system has not been established in the nation, as well as high quantity GHG emission from the disposals to the environments. The latter is the environmental impact at the last life cycle of cooking oil, whereas the nation is the third largest GHG emission country in the world, the most of GHG emissions are derived from deforestation and land use changes, which is closely related to farming activities of palm oil production [1]. It is cited that in Indonesia, most of small business WCO, from such cassava chips, fish crackers and deep fried Tofu manufacturers, is being sold to street food shops and snack vendors for the complete use, causing concern over human health risks (citation made by BPLH, Kota Bogor).

In Japan, most of residents in urban cities are solidifying WCO and disposing as incinerating waste, wasting valuable recyclable energy source. In local areas, the disposal of WCO to drainage is commonly practiced casing deterioration in sewage system, as shown in Table 1.

It is commonly understood that WCO recycling is a good practice to the environment but not economically matched, due to the high labour costs for collection, transportation and recycling processes in Japan.

There are two national and corresponding regional acts in Japan, related to waste disposals. The Water Pollution Prevention Act guides adequate waste of cooking trash and waste cooking oil, as well as right use of detergents to preserve the public water sources, without any specific penalty. On the other hand, the Waste Management Act actively prohibits disposal of waste including waste oil, without good management and control, with severe penalties of less than five year imprisonment or 10,000,000 JPY fine, when the Act is broken. The latter one is especially effective to prevent industrial waste disposals, and the governance of industrial companies in waste management is at high in the nation.

\section{PUBLIC WCO RECYCLING BUSINESSES IN BOGOR AND NIIGATA}

Table 2 shows, recent WCO collection and recycling public businesses conducted by Bogor and Niigata cities.

In 2008, to solve environmental and health issues, the Environmental Directorate of Bogor City initiated the Environmental Partnership Program of WCO recycling [2], with voluntarily collecting activities of large supermarket chain, food companies, church and school communities. In 2013, 800L WCO from big supermarket chain, 500L from food companies, 500L from church communities, and 500 to $800 \mathrm{~L}$ from 23 school communities per month 
respectively, and a total of 70,000L were collected for recycling (citation made by BPLH, Kota Bogor).

The collected WCO was brought to a processing company, and by the ester conversion processes, bio diesel fuel (hereafter BDF) and glycerol were produced. However, due to fluctuating BDF quality, the city bus cooperate with 30 buses under the service used the BDF mixed with the regular diesel fuel, at the ratio of 20 to 80 , and consumed $60 \%$ of the total BDF recycled (citation made by the bus cooperate, Kota Bogor).

In 2005, Niigata City initiated "Rape Flower Plan”, as a series of activities in cultivating rape, harvesting rape seeds, using rape oil, collecting and recycling rape WCO, with a slogan of absorbing carbon dioxide during the plant growth. The same year the local government commenced WCO recycling from school meal centre (used to be cooked at each school, now cooked at central kitchens). In 2013, 43,000L WCO was collected from the school meals and sold to a local company, and recycled to paint and fertilizers, since rice oil currently being used for school meals, is not suitable to $\mathrm{BDF}$, due to the higher viscosity in the low temperatures. The 28,000L WCO from households was collected by residential communities and the local government had 7.65 million JPY deficit in 2013 of the public expenditure forWCO transportation lessprofit from the WCO sales to a BDF company.

TABLE I. SOCIAL, ENVIRONMENTAL ISSUES OF WCO WASTING AND LEGISLATION IN INDONESIA AND JAPAN

\begin{tabular}{|c|c|c|}
\hline Country & Indonesia & Japan \\
\hline $\begin{array}{l}\text { social } \\
\text { issues }\end{array}$ & $\begin{array}{l}\text { most households dispose WCO into } \\
\text { drainage or soil } \\
\text { most industrial WCO be used by } \\
\text { street food shops, snack vendors, } \\
\text { completely concern on health risks }\end{array}$ & $\begin{array}{l}\text { - in urban areas, most WCO solidified } \\
\text { and disposed as incinerating waste } \\
\text { - in local areas WCO disposal into } \\
\text { drainage commonly practiced } \\
\text { - industrial WCO waste under control }\end{array}$ \\
\hline $\begin{array}{l}\text { environ- } \\
\text { mental } \\
\text { issues }\end{array}$ & $\begin{array}{l}\text { severe drainage/edaphic pollution } \\
\text { prodicated GHG emission at } \\
\text { of cooking oil }\end{array}$ & $\begin{array}{l}\text { - waste of recyclable energy in urban } \\
\text { areas } \\
\text { - sewage system deterioration by WCO } \\
\text { disposals in local areas }\end{array}$ \\
\hline legislation & $\begin{array}{l}2014 \text { Bogor City, all industrial WCO } \\
\text { to be recycled }\end{array}$ & $\begin{array}{l}\text { - Water Pollution Prevention Act, no } \\
\text { clear penalties } \\
\text { - industrial WCO be disposed under } \\
\text { responsibility of business operators } \\
\text { - Waste Management Act, less than } 5 y r \\
\text { imprisonment or } 10 \text { million JPY fine }\end{array}$ \\
\hline
\end{tabular}

TABLE II. WCO RECYCLING PUBLIC BUSINESSES IN BOGOR AND NIIGATA CITIES

\begin{tabular}{|c|c|c|}
\hline City & Bogor, Indonesia & Niigata, Japan \\
\hline $\begin{array}{l}\text { Wco } \\
\text { collected } \\
\text { in } 2013 \\
\text { Number of } \\
\text { deposit } \\
\text { stations }\end{array}$ & $\begin{array}{l}\text { total } 70000 \mathrm{~L} \\
23 \text { school association: } 500 ~ 800 \mathrm{~L} / \mathrm{m} \\
\text { big supermarket chain: } 800 \mathrm{~L} / \mathrm{m} \\
\text { food companies: } 500 \mathrm{~L} / \mathrm{m} \\
\text { church communities: } 500 \mathrm{~L} / \mathrm{m} \\
2 \text { or } 3 \text { deposit stations }\end{array}$ & $\begin{array}{l}\text { school meals: } 43000 \mathrm{~L} \text { (not for BDF) } \\
\text { households: } 28000 \mathrm{~L} \text { (city owned) } \\
122 \text { deposit stations including municipal } \\
\text { offices belonged to Niigata City }\end{array}$ \\
\hline $\begin{array}{l}\text { purchasing } \\
\text { price WCO }\end{array}$ & 3500 IRP/L paid to all parties & $\begin{array}{l}20 \mathrm{JPY} / \mathrm{L} \text { only to collecting communities } \\
\text { no payment for individual contributions }\end{array}$ \\
\hline $\begin{array}{l}\text { selling } \\
\text { price WCO }\end{array}$ & $\begin{array}{l}\text { No selling, city owned WCO as } \\
\text { material for BDF process }\end{array}$ & $\begin{array}{l}10 \mathrm{JPY} / \mathrm{L} \text { for BDF company } \\
25 \mathrm{JPY} / \mathrm{L} \text { for non-BDF company }\end{array}$ \\
\hline $\begin{array}{l}\text { purchasing } \\
\text { BDF }\end{array}$ & $\begin{array}{l}31,582 \mathrm{~L}, \text { Bogor City pays } 4500 \mathrm{IRP} / \mathrm{L} \\
\text { City bus cooperate pays } 3500 \mathrm{IRP} / \mathrm{L}\end{array}$ & $\begin{array}{l}17000 \mathrm{~L} \text { of collected } 28000 \mathrm{~L} \text { from } \\
\text { households } 126 \mathrm{JPY} / \mathrm{L}\end{array}$ \\
\hline $\begin{array}{l}\text { public BDF } \\
\text { use }\end{array}$ & $\begin{array}{l}30 \text { city buses ( } 20 \% \text { BDF in fuel) } \\
60 \% \text { BDF consumed by city vehicles } \\
\text { remain sold to market, detail unknown }\end{array}$ & $\begin{array}{l}36 \text { city utilities ( } 100 \% \text { BDF in fuel) } \\
60 \% \text { BDF consumed by city vehicles } \\
\text { remain sold as heavy eq. boiler fuel }\end{array}$ \\
\hline
\end{tabular}

Table 2 shows the similarities of those local governments, in total WCO amount collected, purchasing price and number of city vehicles being used to consume the recycled fuel. Those cities also consumed $60 \%$ of total recycled bio diesel fuel for their vehicle operations.

Table 3 summarized issues in the public and private WCO recycling businesses and constrains on private business development. Those issues and constrains well illustrate the economic and technical background of those two nations, whereas Japan suffers from the high labour costs and Indonesia from the quality control. In other words, it is clearly highlighted that both cities are able to solve the issues if claimed constraints are eliminated or solved.

TABLE III. ISSUES IN PUBLIC AND PRIVATE WCO RECYCLING BUSINESSES AND CONSTRAINTS

\begin{tabular}{|c|c|c|}
\hline City & Bogor, Indonesia & Niigata, Japan \\
\hline $\begin{array}{l}\text { issues as } \\
\text { public } \\
\text { business }\end{array}$ & $\begin{array}{l}\text { popular demand to reduce GHG } \\
\text { emission and health risks, but } \\
\text { fluctuating BDF quality reduces BDF } \\
\text { consumption by city buses }\end{array}$ & $\begin{array}{l}\text { - utilization and buyers of recycled } \\
\text { BDF is limited, few marketability } \\
\text { - too many WCO deposit stations } \\
\text { increased transport costs }\end{array}$ \\
\hline $\begin{array}{l}\text { existing } \\
\text { recycling } \\
\text { private } \\
\text { businesses }\end{array}$ & $\begin{array}{l}\text { a contracted company conducts } \\
\text { recycling processes but no } \\
\text { privatizing of the whole operations }\end{array}$ & $\begin{array}{l}\text { transportation of collected WCO } \\
\text { conducted by contracted companies } \\
\text { paid by city } \\
\text { one NPO conducts self collection/ } \\
\text { transportation for its own BDF use }\end{array}$ \\
\hline $\begin{array}{l}\text { constraints } \\
\text { for private } \\
\text { businesses } \\
\text { development }\end{array}$ & $\begin{array}{l}\text { a whole privatized business by the } \\
\text { city bus cooperate is expected, but } \\
\text { can not afford to construct a BDF } \\
\text { plant with quality control }\end{array}$ & $\begin{array}{l}\text { - labor costs for collection, } \\
\text { transportation, recycling refrains } \\
\text { privatizing of WCO recycling } \\
\text { business }\end{array}$ \\
\hline
\end{tabular}

Bogor city seems much easier to solve the technical constraint as labour costs are not the major issue, but Niigata seems more difficult to encounter the economic constraints. The previously mentioned 7.65 million JPY deficit in WCO recycling public business is being compensated by subsidies from charged waste bags by Niigata City, but this kind of costs can not be affordable by private business.

A NPO (non profit making organization) in Niigata conducts self WCO collection and transportation to a BDF factory for its own BDF use by utilities, and it has no interest to widen such a business as it makes a substantial deficit. Therefore, in Japan, unless labour for collection and transportation is totally voluntarily provided, it seems no chance to make the WCO recycling business in the private sector.

\section{SURVEY ON COOKING OIL USE AND DISPOSAL}

In February 2014, a questionnaire survey by a paper format and a web application program, was conducted at three high schools in Bogor City, and a total of 188 valid household responds on detail cooking oil use and disposals was obtained. The monthly consumption of cooking oil varied, but the $67 \%$ of households consumed between 2.0 and $4.9 \mathrm{~L}$ with an average consumption of $3.6 \mathrm{~L}$. The $51 \%$ households disposed WCO to drainage, the $17 \%$ to soil, the $15 \%$ gave WCO to their maids, and the $11 \%$ households contributed their WCO to City's recycling program (Figure $1)$. 


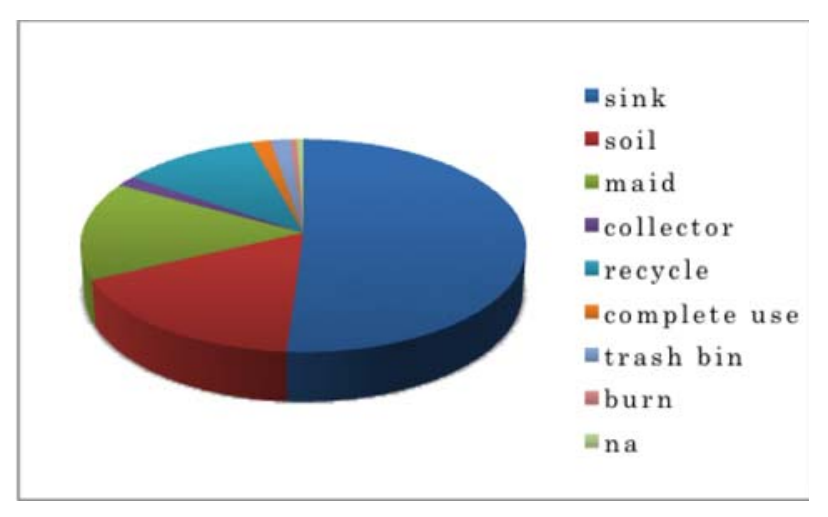

Figure 1. Methods of WCO disposal in households in Bogor $(n=188)$

The 29\% households disposed WCO less than 500ml per month, the $10 \%$ between 500 and $999 \mathrm{ml}$, the $12 \%$ between 1000 and $1499 \mathrm{ml}$, with an average of $796 \mathrm{ml}$. However, 73 households of the $39 \%$, did not recognize the amount of disposals.

\section{LIFE CYCLE IMPACTS OF COOKING OIL IN BOGOR}

The life cycle impacts in GHG emission of three WCO disposal cases and the recycling were estimated based on the previous study [3], using factory data of the BDF plant in Bogor, and a series of LCA studies conducted in the nation and other regions.

Table 4 shows the life cycle impacts of WCO disposal to drainage, WCO disposal to soil, complete use of cooking oil, and WCO recycling to BDF in Bogor, adapting the monthly averages in cooking oil consumption of $3.6 \mathrm{~L}$ and disposal of $0.796 \mathrm{~L}$ from the survey result previously reported. Figure 2 illustrates the GHG emission of those four cases as in $\mathrm{kg}$ CO2e/FU. Nearly $3.0 \mathrm{~kg} \mathrm{CO}_{2}$ equivalent GHG was emitted to produce $3.6 \mathrm{~L}$ cooking oil, with relatively small components of GHG emission in BDF production (energy and materials) and that from drainage origin methane in discharged waste water from the BDF factory. The result shows a substantial increase of GHG by fossil diesel fuel (RDF) production as well as glycerine production and disposal. The life cycle impact analysis shows the reduction in GHG emission, if WCO was recycled instead of disposals to drainage, soil and the complete use, the last commonly seen in street food shops in Indonesia [4].

TABLE IV. LIFE CYCLE IMPACTS OF 3.6L COOKING OIL USE AND 0.796L DISPOSAL OR RECYCLING

GHG em ission $\mathrm{kg}-\mathrm{C} 02 \mathrm{e} / \mathrm{FU}$

\begin{tabular}{|l|l|l|l|l|l|l|l|l|l|l}
\hline & $\begin{array}{l}\text { cookng oil } \\
\text { production }\end{array}$ & $\begin{array}{l}\text { C C } \\
\text { transport }\end{array}$ & $\begin{array}{l}\text { BDF } \\
\text { production }\end{array}$ & $\begin{array}{l}\text { BDF } \\
\text { transport }\end{array}$ & $\begin{array}{l}\text { RDF } \\
\text { production }\end{array}$ & $\begin{array}{l}\text { m ethane } \\
\text { (dranage })\end{array}$ & $\begin{array}{l}\text { GHG of } \\
\text { carbon in } \\
\text { m ethanol }\end{array}$ & $\begin{array}{l}\text { glycern } \\
\text { production } \\
\text { \& disposal }\end{array}$ & Total & $\begin{array}{l}\text { GHG } \\
\text { reduction }\end{array}$ \\
\hline D ranage disposa & $2.981 \mathrm{E}+00$ & $0.000 \mathrm{E}+00$ & $0.000 \mathrm{E}+00$ & $0.000 \mathrm{E}+00$ & $1.441 \mathrm{E}+00$ & $1.136 \mathrm{E}-02$ & $0.000 \mathrm{E}+00$ & $9.574 \mathrm{E}-01$ & $5.391 \mathrm{E}+00$ & $1.677 \mathrm{E}+00$ \\
\hline Edaphic disposal & $2.981 \mathrm{E}+00$ & $0.000 \mathrm{E}+00$ & $0.000 \mathrm{E}+00$ & $0.000 \mathrm{E}+00$ & $1.441 \mathrm{E}+00$ & $5.681 \mathrm{E}-02$ & $0.000 \mathrm{E}+00$ & $9.574 \mathrm{E}-01$ & $5.437 \mathrm{E}+00$ & $1.722 \mathrm{E}+00$ \\
\hline Com plete use & $2.981 \mathrm{E}+00$ & $4.824 \mathrm{E}-03$ & $0.000 \mathrm{E}+00$ & $0.000 \mathrm{E}+00$ & $1.441 \mathrm{E}+00$ & $0.000 \mathrm{E}+00$ & $0.000 \mathrm{E}+00$ & $9.574 \mathrm{E}-01$ & $5.385 \mathrm{E}+00$ & $1.670 \mathrm{E}+00$ \\
\hline W C 0 recyc ling & $2.981 \mathrm{E}+00$ & $4.824 \mathrm{E}-03$ & $4.908 \mathrm{E}-01$ & $4.014 \mathrm{E}-03$ & $0.000 \mathrm{E}+00$ & $1.942 \mathrm{E}-01$ & $3.947 \mathrm{E}-02$ & $0.000 \mathrm{E}+00$ & $3.714 \mathrm{E}+00$ & \\
\hline
\end{tabular}

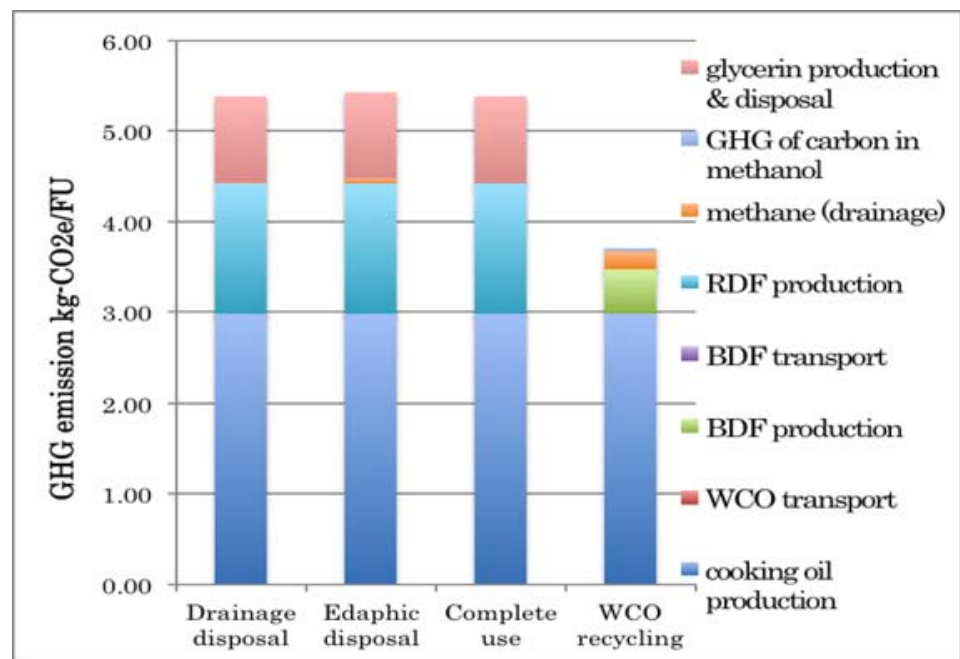

Figure 2. GHG emission of cooking oil use and disposals or recycling 


\section{DISCUSSION}

The comparison of the life cycle impacts of WCO disposal methods clearly indicated the environmental advantage of the WCO recycling, as GHG emission of the same calorific amount of fossil diesel fuel (RDF, shown as in the light blue bar components in Figure 2.) was much larger than one of the BDF production (as in the green bar component), adding the methane generation in the drainage water (as in the orange bar component). As shown in Table 4., GHG emissions of WCO and BDF transportation were very small, compared with other life cycle impacts. The differences of the total GHG emissions in the drainage disposal, the edaphic disposal, and the complete use, from the recycling were more or less the same, $1.67-1.72 \mathrm{~kg} \mathrm{CO}_{2}$.

In this study, we did not apply the cooking oil reduction model, which was used in the previous studies [2][3][4], as a half of the 188 households did not repeatedly use the cooking oil, and other half only once repeated. Therefore, it was not necessary to consider the residual effects on cooking oil quantity of the recycling and the complete use cases.

The environmentally advantageous WCO recycling does not necessarily encourage the both regional governments to widen the recycling activities due to the technical and economical constrains (Table 3). The Bogor City has the great advantage of less labour costs for the whole operations but the fluctuation of the BDF quality prevents the $100 \%$ fuel use by the city bus cooperate. On the other hand, Niigata City seems to have some redundancy in the commercial flow. The local government sold the WCO to the BDF company at seller's costs of WCO transportation, and it purchased the BDF products from the companies. 122 deposit stations in Niigata City makes also a great cost for transportation of collected WCO to the BDF company. The deficit of 7.65 million JPY in 2013 does not imply any possibility of the privatization of this public business.

Further study is necessary to elaborate business models of the whole WCO recycling in the Bogor City case, be conducted by the city bus cooperate, taking the advantages of the quantitative and qualitative control of the material procurement and production, as well as in the usage.

\section{ACKNOWLEDGMENT}

This study was conducted between Centre for Environmental Technology, Agency for Assessment \& Application of Technology (BPPT) of Republic of Indonesia, and Research Organization for Information and Systems (ROIS) of Japan, affiliated by the Data Centric Science Research Commons, as well as JSPS's research fund No. 22240030.

\section{REFERENCES}

[1] Haruhiro Fujita, Koji Okuhara, Katsuyuki Nakano and HiroeTsubaki, Environmental Analyses of Waste Cooking Oil Recycling and Complete Use Practices in Bogor, Indonesia, Proceedings of International Conference on Technology, Informatics, Management, Engineering and Environment, June 23-26, 2013, Bandung, Indonesia, pp. 28-31.

[2] ENVIRONMENTAL PARTNERSHIP PROGRAM, BPLH Kota Bogor, 2011, Republic of Indoneisa.

[3] KatsuyukiNakamo, Haruhiro Fujita, JokoPrayitnoSusanto, DadangSupriatna, Koji Okuhara, and HiroeTsubaki, Life Cycle Impact Assessment on Climate Change of Recycling to Bio Diesel Fuen and Reuse of Used Cooking Oil: Case Study in Bogor, Indonesia. Journal of Life Cycle Assessment, Japan, Vol.9, No.4, 315-323, 2013.

[4] Haruhiro Fujita, Atsushi Yoshimoto, KatsuyukiNakamo, Koji Okuhara, Noriaki Koide, DadangSupriatna, GHG emission production by waste cooking oil recycling in environmental partnership program of Bogor City, Proceedings of 2nd International Conference on Adaptive and Intelligent Agroindustry (ICAIA), 2013, 10-16. 